\title{
Involvement of NF-KB and HSP70 signaling pathways in the apoptosis of MDA-MB-23 I cells induced by a prenylated xanthone compound, $\alpha$-mangostin, from Cratoxylum arborescens [Corrigendum]
}

Ibrahim MY, Hashim NM, Mohan S, et al. Drug Des Devel

Ther. 2014;8:2193-2211.

On page 2193, author affiliations, "Department of Molecular Medicine, Faculty of Medicine, University of Malaya, Kuala Lumpur, Malaysia" should be "Department of Biomedical Science, Faculty of Medicine, University of Malaya, Kuala Lumpur, Malaysia".

Introduction, first paragraph, the text should read: "Breast cancer has become a major cause of morbidity and mortality in women globally. The American Cancer Society (ACS) reported that breast cancer incidence has an estimation of $26 \%$ of all new cancer cases, which is the highest in ratio among all the cancers in American women. ${ }^{1}$ The National Cancer Registry (NCR) in Malaysia has reported th in twenty Malaysian women are at a risk of acquiring cancer in their lifetime. ${ }^{2}$ The incidence rate in Malaysia is still considered low if compared to Europe and United States. ${ }^{3}$ Up to $70 \%$ of breast can velopment causes occur in women is reported to of envin mental factors and lifestyle. ${ }^{4,5}$ "

Introduction, secor paragr $\mathrm{h}$, fin intence, the text should read: "Radìa n th apy has become a valuable tool among cance creatmen trategi for the control of local and regig $M$ seases after with the invention of the linear accelerato 'ut, like surgery, radiation therapy alone ca Ducleate mo tatic cancer."

iscussion, ist paragraph, first sentence, the text should 1. "Apop" sis has a vital role in many functions, ranging from development to adult tissue homeostasis. ${ }^{32}$ ",

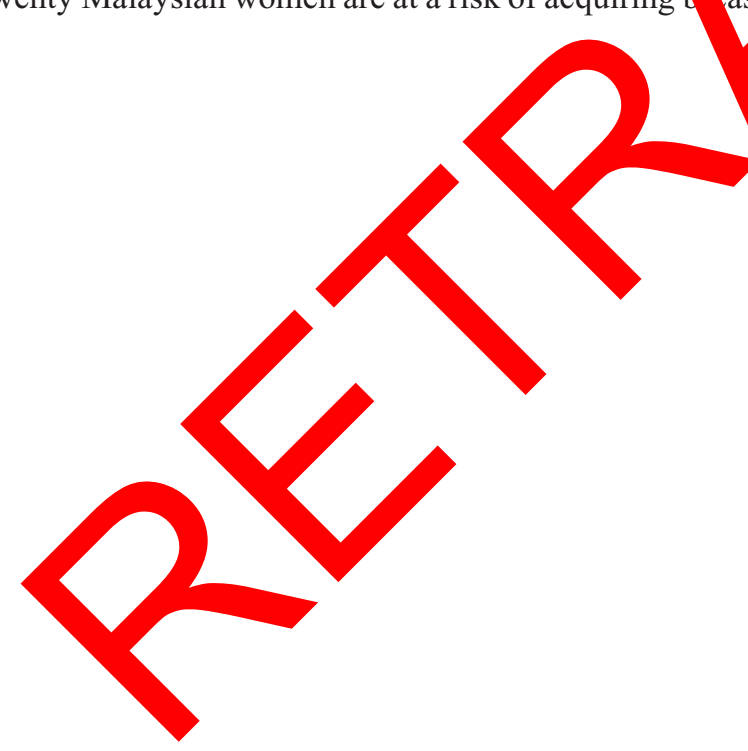

Drug Design, Development and Therapy

Dovepress

\section{Publish your work in this journal}

Drug Design, Development and Therapy is an international, peerreviewed open-access journal that spans the spectrum of drug design and development through to clinical applications. Clinical outcomes, patient safety, and programs for the development and effective, safe, and sustained use of medicines are a feature of the journal, which has also been accepted for indexing on PubMed Central. The manuscript management system is completely online and includes a very quick and fair peer-review system, which is all easy to use. Visit http://www.dovepress.com/testimonials.php to read real quotes from published authors. 